DE DE GRUYTER

OPEN

G

DOI: 10.1515/genst -2015-0005

\title{
READING THE SILENCE IN THE MATERNAL TEXT OF CAROL
} SHIELDS' UNLESS

\author{
ŞEYDA İNCEOĞLU \\ Pamukkale University \\ Çamlaraltı Mh., Pamukkale Üniversitesi, \\ Merkez/Denizli Province, Turkey \\ sinceoglu@pau.edu.tr
}

\begin{abstract}
This article scrutinizes the representation of silence in Carol Shields' novel Unless. It analyses the problematic behind the mother-daughter relationship between Reta Winters and her daughter Norah by applying the theories of Cixous, Kristeva, Chodorow and Irigaray in relation to maternity and identity. Reta Winters' so-called ideal life is called into question by her daughter Norah's sitting on the streets with a sign board on her chest with GOODNESS written on it. Reta wonders what she has done wrong throughout her life, and eventually, while writing a novel, starts to realize that she has never created maternal discourse with her daughter. Thus, as the novel unfolds in chapters most of which have adverbs or prepositions as their titles, Reta creates a maternal text, both oral and written, by the end of the story.
\end{abstract}

Keywords: Carol Shields, goodness, maternity, mother-daughter relationship, Unless.

\section{Introduction}


With your milk, Mother, I swallowed ice. And here I am now, my insides frozen. And I walk with even more difficulty than you do, and I move even less. You flowed into me, and that hot liquid became poison, paralyzing me (Irigaray 1981:60).

Luce Irigaray, reflecting on the mother-daughter relationship, states that the mother transfers her own passivity to her new-born daughter through her milk. However, this passivity is also transmitted to the mother by another woman: her own mother. Thus, as Cixous asserts, woman either becomes passive or does not exist as an individual in a patriarchal culture (Cixous 1986:561).

In contrast to Freud and Lacan, Julia Kristeva emphasizes the importance of the maternal function in the development of subjectivity and access to culture and language. She calls for a new discourse of maternity in order to re-establish a meaningful relationship between the mother and the daughter (Ritzer 2004:424). This new discourse of maternity, as emphasized by Kristeva, is rewoven in Carol Shields' novel Unless, which will be discussed in this article in terms of the problematic behind the motherdaughter relationship. The so-called 'ideal' life of Reta Winters is abandoned when her eldest daughter Norah ends up on a street corner begging and holding a card on which is written the word 'GOODNESS'. Long before her mother does so, nineteen-year-old Norah realizes that there is no 'goodness', in particular, none that is acknowledged to originate in a woman, in this world. Her mother is trapped in the traditional discourse that sees the female within a traditional family heritage in which the mother/wife raises the children and takes care of the house and does not exist in the outer 
world. Norah's umbilical cord is cut when she is confronted with 'this truth'. What Norah also realizes is what the word 'goodness' refers to: the unity, the association which she and her mother lack. The word 'good' comes etymologically from:

Old English god (with a long “o”) “virtuous; desirable; valid; considerable,” probably originally "having the right or desirable quality," from Proto-Germanic *gothaz (cognates: Old Norse goðr, Dutch goed, Old High German guot, German gut, Gothic gops), originally “fit, adequate, belonging together," from PIE root *ghedh- "to unite, be associated, suitable" (emphasis mine, Dictionary of Etymology).

Since they have never had a connection either as mother and daughter or as woman to woman, mutual communication between them has never been achieved, due to the transference of powerful patriarchal discourse even from one matriarch to another. In fact, what is needed among women is only to connect their languages to each other in order to form a sisterhood between them. As E. M. Forster (2007:202) says, “Only connect! That was the whole of her sermon. Only connect the prose and the passion, and both will be exalted, and human love will be seen at its height. Live in fragments no longer. Only connect, and the beast and the monk, robbed of the isolation that is life to either, will die”. Through connection of words, a maternal language will be created between Reta and her daughter Norah and this language will allow them to gather fragmented pieces together so as to reach reconciliation not only with their own identities but also with each other's identity.

\section{Mummification of Women by Male Discourse}


In spite of the fact that Reta and her husband Tom had been rebellious towards all kinds of institutionalized conventions in their youth, they ended up being caught up in the patriarchal discourse that was imposed upon them. All the actions they thought were rebellious, such as not getting officially married, replacing their unofficial wedding reception with a pizza party, and Tom's not attending his graduation ceremony, only represent their so-called anti-system behaviours. Reta thinks that she has everything necessary for the "useful monotony of happiness" (Shields 2003:1): a loving, faithful, family physician husband, three intelligent, lively, loving daughters (though Norah, her eldest daughter, has left home to live with her boy-friend), and their seven-year-old golden retriever named Pet, which all suggest the family's traditional, non-authentic and conventional side. Their house on a steep hillside, which is a hundred years old, also represents their being a part of the system. What is noteworthy too is that the family did not build the house themselves but only bought it from the McGinns family; in other words, they took on the patriarchal heritage. In this traditional patriarchal picture, while Tom is a descendant of his own family physician father, Reta is presented as an angel in the house; however, she tries to contradict this image by saying that she has her own writing, or more precisely her translating. She translates the works of Danielle Westerman, who is a poet and also a lecturer at the University of Toronto. Reta's French background comes from her Québécoise mother and her English side is from her English father. Reta's translation of Danielle's texts signifies her desire to reconnect herself to her dead mother. According to Irigaray, the daughter mourns the loss of the mother and fails in constructing her own individuality by perpetuating the mother's role into the future. According to 
Irigaray: "In a sense we need to say goodbye to maternal omnipotence (the last refuge) and establish a woman-to-woman relationship of reciprocity with our mothers, in which they might possibly also feel themselves to be our daughters. That is an indispensable precondition for our emancipation from the authority of fathers” (Whitford 1991:50). In spite of the fact that her mother is dead, Reta still feels their failure to build a maternal discourse between them, and this absence is transferred onto the writer Danielle Westerman, who is in her eighties, with Reta desiring to revive a maternal language between them. Rachel Josefowitz Siegel says that "when an old woman walks into the room, she could be our mother, she could be our grandmother - she is not me, not us. Old woman is mother and mother is old; old woman is other. Old woman is a role, an image; a stereotype - she is not a person [...] Old woman is not me; old woman is not what I want to be.” (Caplan 2000:xii). This educated elderly woman, Danielle, represents Reta's dead mother, with whom she failed to fulfil the mother-daughter relationship, more than this, it will be seen throughout the novel that Reta is trapped within the patriarchal restraints due to the lack of maternal discourse in her life, not only with her own mother, but also with Danielle Westerman, with her mother-in-law, and with her own daughter.

Cixous says that woman "does not enter into the oppositions... [and] does not make a couple with the father" (Cixous 1986:64); in the same way Norah never tries to communicate with her father. This is because Tom, as a medical doctor, upholds "the idea of diagnosis and healing," "a rhythmic arc of cause and effect” (Shields 2003:264), and proposes a scientific interpretation for Norah's situation. However, what Norah needs is only connection to a maternal discourse that could enable her to establish an autonomous female identity. Thus, she has to be involved in a relationship 
with her mother in order to achieve this womanhood identity. An undefined mother-daughter relationship renders it difficult for both parties to survive in the patriarchal discourse. The paternal discourse should be replaced by a special language that is created between the mother and the daughter. However, if the mother fails to act as the infant's "external ego" (in Margaret Mahler's term), the daughter has to develop her capacities on her own if she is to connect herself to the outside world as a woman, as Chodorow implies and it becomes impossible to establish a maternal discourse (Chodorow 1979:58). When Norah tries to connect with her mother by discussing "to find where she fits in", Reta only suggests that she go to the hospital to talk to someone in the counselling area and puts an emphasis on the word "Today" (Shields 2003:131). However, what Norah really wants to do is to have a womanly conversation with her mother in order to search for the self.

To assert an autonomous identity in society, women have to have a language, a text of their own. For this reason, Reta will gradually identify herself through the connection to her daughter while she is writing her novels. Adverbs, prepositions and conjunctions woven into the text at the beginning of each chapter will reconnect Reta and Norah even as they enable Reta to write her novel. Reta, which in Greek means a speaker, goes beyond the meaning of her name and becomes a writer by the end of the novel; while she is telling her story orally, she takes it to a further dimension by writing a novel by drawing on her newly-gained self-awareness. Reta is also a short form of Marguerite, which means daisy in French. It is interesting to see that while Reta is indicating that "from [my] her mother [I] she developed [my] her love of flowers, she confesses that [I] she liked to tear the silk of the petals between [my] her fingers, rubbing the pollen into 
[my] her hands” (148). Consciously or unconsciously, she destroys what is passed on to her by her mother, since she could not establish a discourse with her. On the other hand, pollen can also be associated with being prolific, and Reta's rubbing the pollen into her hands can be linked to her transferring this quality to her hands in order to be able to write. Reta is not a commonly used name; it is also a variant form of other names such as Rita, Reda, Reeda, Reeta, Rheta and Rhetta. Her name's subordination to other names can also be associated with her being a translator and metaphorically with her being an extension of Danielle's body (not of her own mother's). The name Danielle means beautiful, intelligent, and strong female. Thus Reta attaches herself to a female whom she considers more powerful than herself. However, she has to detach herself from Danielle in order to establish an autonomous identity as a woman.

The name Reta gives to her daughter, Norah, is also a variant of other names, including Annora (Latin), Eleanor (Greek), Honor (Latin), Leonora (Greek) and Nora (English), and the meaning of Norah is 'honour'; 'sun’s ray', 'shining light'; 'woman of honour'; 'compassion'; 'light'. In addition, Nora or Norah comes from the Hebrew menorah "candlestick," from the Semitic stem $n-w-r$ "to give light, shine" (Arabic nar "fire," manarah candlestick, lighthouse, tower of a mosque" (Dictionary of Etymology). Norah's name, despite being a variant form of another name, has a powerful meaning of its own. Yet Danielle suggests that it does not offer a meaning: "She believes that Norah has simply succumbed to the traditional refuge of women without power; she has accepted in its stead complete powerlessness, total passivity, a kind of impotent piety. In doing nothing, she has claimed everything” (Shields 2003:104). However, it is not only acceptance but also a powerful discourse that she constitutes. 
There are some parallels between Norah in Unless and Nora in Henrik Ibsen's A Doll's House. Norah is reminiscent of Ibsen's Nora, who is represented as a victim of Victorian restraints and sets herself free from them by leaving everything behind. Norah also becomes detached from her family consciously and voluntarily in order for the writer to show her reaction. This reaction and her ending up on a street corner begging and holding a piece of card on which is written the word GOODNESS also reminds us of Philomela, the character in Greek mythology who weaves the story of how she was raped by her brother-in-law, a powerful king, into a tapestry, since she has been silenced by her tongue having been cut out. Like Philomela, Norah communicates a great deal through the single word GOODNESS.

Roland Barthes (1990:47) writes in his Pleasure of the Text that storytelling is a way of searching for one's origin. When Reta plans to start her quest for the self, Danielle is quite disappointed with her decision to write a novel instead of concentrating on the work of translating her books: “Nevertheless she can't understand why I'm not getting on with the translation of her memoirs or why, instead, I'm writing another novel. She has, though she would never confess to it, a deep, almost eighteenth-century suspicion of fiction” (Shields 2003:105). There is a parallelism between Reta's starting her inner journey and her writing her novel. Reta has to solve the mystery of her identity, her role as a mother, as a woman, and then she has to integrate herself to the discourse that she will establish. When Reta starts to write instead of translating she forms a relation, or in other words a reconnection, with her daughter, with whom she has unconsciously stopped communicating. While recalling some memories of Norah, she comments on how Norah controlled her bad dreams at night when she was four or five 
years old: "[I] she just turn[s] [my] her head around on the pillow," (89) she always overcame her fear of bad dreams through silence. Similarly, Norah's reaction to the hypocritical patriarchal system that condemns women to the veil whether they are in Canada or in an Islamic country, as will be revealed as the novel progresses, appears to be a silent passivity but in fact includes a powerful discourse. The insertion of a Muslim woman, a bright Indian rug (49) and a caftan made of African cotton (70) into the text signifies the East versus Western civilization. In spite of the image that Western civilizations treat all people equally regardless of sex, ethnicity and so on and offer 'civilization', there is hypocrisy at work behind the scenes. Although the West is thought of as signifying freedom, as being a civilization in which people should have the right to be treated equally and live in comfort, it is observed that this is not the case - rather the reverse. The fact that the name Norah means 'light' and that its origin is Arabic according to some sources is closely linked with Norah's trying to save the Muslim woman in her veil or burka who sets fire to herself in the centre of Toronto. Norah awakens into consciousness and self-awareness long before her mother does.

In Plato's world, woman is silenced, since he silences her by making her the material of metaphor. According to him, she is the receptacle, the womb that holds men prisoners, the immanence of embodiment, and the maternal (Walker 1998:12). However, according to the novel Unless, it is the womb, which is defined by the patriarchal discourse, that holds women prisoners: "THANK YOU FOR releasing me from your loins,” my middle daughter Christine said to me today, October twelfth, which happens to be her seventeenth birthday. Loins. Where had she got a word like loins? "It's from Tom Wolfe's novel,” she explained. "It means uterus. Or else womb.” (Shields 2003:153). The womb, defined by a man called Wolfe who could 
be considered a very clear representative of a patriarch, is seen as a prison by Reta's daughter. Because it is not only Norah who suffers; rather, all women experience the very same pain in their bodies. Irigaray suggests immense bodily suffering as being a language, so we can decipher Norah's physical suffering due to her burnt hands as her attempt to construct a language of own. While Reta tries to establish a meaningful relation with Danielle, in order to take care of her 'closest companion', her surrogate mother, she ignores her relation with Norah.

While patriarchal discourse mummifies women by imposing upon them the roles of mother and wife at home and appearing as virtuous housewives outside the house, maternal discourse seeks something rather different from these roles, something that is to be fulfilled by considering the connection between mother and daughter. Kristeva identifies the maternal with the unspeakable. Although the maternal/semiotic is crucial to the Kristevan theory of art as the exemplary subversive practice, the mother remains, as the phallotext defines her, a passive instinctual force that does not speak, but is spoken by the male (Hirsch 1989:172-173). The unspeakable does not bring Reta and Norah together, so woman-defined motherhood becomes important in the lives of both women. When Reta forms a relationship with her daughter, she reaches an understanding of what it is to be a woman. In order to connect or reconnect herself, she has to have a woman to woman relationship. This relationship starts with the shift in Reta's relation with Danielle since that is a kind of replica of her relation with her own mother. As she disconnects herself from Danielle, she connects herself to her daughter. In this way, she becomes a writer rather than just a translator from another language. She writes her own text, in other words, the maternal discourse she speaks. 
The meaning of motherhood has to be redefined in order to be fulfilled by both mothers and daughters. While at first she is only a mediator for the texts of her surrogate mother Danielle, Reta later becomes the artist, the narrator, the mother, as opposed to simply acting out, in her daily routine, the roles attributed to a mother/woman within the traditional patriarchal discourse. Indeed Reta, by using conjunctions, prepositions and adjectives (such as unless, therefore, also, not yet, instead etc.) in her text, reconstitutes her identity as a woman and reconnects herself to her daughter. While a physical mother and father do exist for Norah, there is no mental relation between them. This metaphorical absence of the family results in Norah's taking the responsibility for both herself and other people under the claim of 'GOODNESS'. Thus, beyond mere motherhood, a true communication, emotional and mental connection becomes important. The burns on Norah's hands and wrists caused by her attempt to save the Muslim woman who set herself alight are the signs of both physical and psychological suffering. It is significant that as Norah rushes forward to extinguish the flames, the plastic dish rack which she has bought for the apartment she lives in with her boyfriend becomes a second fire, and the plastic bag in which it was being carried burn themselves onto Norah's flesh (Shields 2003:315). The plastic dish rack, the symbol of woman's imprisonment in the kitchen or private sphere, becomes the source of her suffering.

When Norah's mother Reta starts writing her second novel Thyme in Bloom, which she regards as a sequel to My Thyme is Up, she feels the gradual development in her self; Roland Barthes, as noted above, suggested in Pleasure of the Text that storytelling is a way of searching for one's origin. Thus, Reta comes to an understanding of her own mother, of her 
mother-in-law and consequently of her daughter. However, this quest and understanding which is obvious in her second text is realized by a patriarch, her editor Arthur Springer, who regards her first novel as only "a light romantic comedy about quite ordinary people" but the second one as "a novel about human yearning” (243). Once Arthur has made this distinction, he uses his authority as her editor to ask for some changes which will again be a continuation of patriarchal discourse. He tries to suggest to Reta how the story of Alicia and Roman should end. "I think of the final chapter as the kiln. You've made the pot, Reta, the clay is still malleable, but the ending will harden your words into something enduring and beautiful. Or else beautiful and ethereal” (277).

The most significant difference between these two novels is that in the first of them, Alicia is the editor of a magazine, while in the second she makes the decision to study Chinese women's poetry at university. This is noteworthy since it can be taken as a sign of Reta's growing into maturity and becoming aware of the identity of a woman being something above and beyond merely being a mother/wife. Through the character of Alicia, Reta realizes the liberating power of art and also reconciles the Western woman with the Eastern. This sisterhood is explained by Reta as follows: "I would become a woman writing about a woman writing about women writing...” (268).

\section{Conclusion}

Reta's writing of her own book enables Danielle Westerman, at the end of the novel, to decide to translate her own works in future and Reta comments on this as follows: "Danielle Westerman has given up on me. She has decided to translate her own book, and the portions she has shown me 
are both accurate and charming, that concept I thought I had given up onbut now I see that charm can be a gesture toward the authentic when it allows itself to be caught in the wings of an updraft and when it pushes its way into a different kind of cultural weather” (319). Thus it becomes obvious at the end of the novel that unless cultural integration and sisterhood between women is created, it is not possible to form a female discourse which asserts their integrity and existential selves against the patriarchal discourse. The progress and reattachment of women is lit and ignited by Norah, who is in fact the last link in the chain of this sisterhood.

\section{References}

Atwood, Margaret. 1979. Surfacing. London: Virago.

Barthes, Roland. 1990 (1973). Pleasure of the Text. Trans. Richard Miller. Oxford: Basil Blackwell.

Caplan, Paula. 2000. The New Don't Blame Mother: Mending the Mother-Daughter Relationship. London and New York: Routledge.

Chodorow, Nancy. 1979. The Reproduction of Mothering: Psychoanalysis and the Sociology of Gender. Berkeley, Los Angeles and London: University of California Press.

Cixous, Hélène and Catherine Clement. 1986. The Newly Born Woman. trans. Betsy Wing. Minneapolis: University of Minnesota Press.

Forster, Edward Morgan. 2007. Howards End (with an Introduction by Samuel Hynes).

New York: Bantam Dell.

Hirsch, Marianne. 1989. The Mother/Daughter Plot: Narrative, Psychoanalysis, Feminism. Bloomington, IN: Indiana University Press.

Irigaray, Luce. 1991. The Irigaray Reader. Ed. and with an introduction by Margaret Whitford. Oxford and Massachusetts: Blackwell Publishers Ltd. . 1981. “And the One Doesn’t Stir Without the Other”, trans. H. V. Wenzel, Signs $7(1)$.

Jacobs, Amber. 2007. On Matricide: Myth, Psychoanalysis, and the Law of the Mother. New York: Colombia University Press. 
Kristeva, Julia. 1980. Desire in Language: A Semiotic Approach to Literature and Art.

Leon S. Roudiez. (Ed.). New York: Columbia University Press.

Ritzer, George (Ed.). 2004. Encyclopedia of Social Theory. Sage Publications.

Shields, Carol. 2003. Unless. London and New York: Fourth Estate.

Walker, Michelle Boulous. 1998. Philosophy and the Maternal Body: Reading Silence. London and New York: Routledge.

Whitford, Margaret. 1991. Luce Irigaray: Philosophy in the Feminine. London and New York: Routledge. 